\title{
RELEVANSI BUDAYA PATRIAKI DENGAN PARTISIPASI POLITIK DAN KETERWAKILAN PEREMPUAN DI PARLEMEN
}

\begin{abstract}
Abraham Nurcahyo *
Abstrak

Bentuk penentangan perempuan atas kuasa laki-laki tidak terlepas dari sistem patriarki yang tidak adil. Menempatkan perempuan sebagai bayang-bayang laki-laki. Masyarakat patriarki sejak awal menganggap bahwa laki-laki lebih kuat dibandingkan perempuan baik dalam kehidupan pribadi, keluarga, masyarakat, maupun bernegara. Budaya patriarki dan nilai-nilai sosial di Indonesia menuntut perempuan untuk tidak berpartisipasi di ranah politik maupun pemerintahan. Sistem dan arah kebijakan pemerintah terhadap isu perempuan kian responsif jender. Namun demikian, posisi perempuan tetap rentan terhadap berbagai bentuk manipulasi politik dan sering dipakai sebagai alat legitimasi. Pasal 27 ayat (1) Undang-Undang Dasar Negara Republik Indonesia Tahun 1945 menegaskan, bahwa kedudukan laki-laki dan perempuan sebagai warga negara adalah setara. Kuota minimal 30\% keterwakilan perempuan diterapkan dalam Undang-Undang Nomor 2 Tahun 2008 tentang Partai Politik. Kurangnya keseimbangan gender di sektor politik dan pemerintahan dapat menghambat partisipasi perempuan dalam ranah publik. Dalam perspektif perempuan, politik haruslah mencakup seluruh kehidupan baik di ranah publik maupun privat.
\end{abstract}

\section{Kata kunci : Budaya Patriaki, Partisipasi Politik, Keterwakilan Perempuan}

\section{Pengantar}

Realitas sejarah menunjukkan bahwa perempuan telah ikut berperan pada masa pergerakan, Sebut saja dari Minangkabau misalnya, ada Rasuna Said, Rohana Kudus, dan Rasimah Ismail, mereka mampu membangkitkan kesadaran dan meningkatkan rasa nasionalisme di kalangan perempuan. Sejarah juga mencatat, dua bulan setelah Sumpah Pemuda dideklarasikan, persisnya pada tanggal 22 Desember 1928, sekitar 30 organisasi perempuan dari 12 kota di Jawa dan Sumatera berkumpul untuk menyelenggarakan Kongres Perempuan pertama di Yogyakarta.

Gerakan perempuan di Indonesia memiliki keterlibatan aktif di bidang politik namun masih ada kesenjangan dalam hal partisipasi dan keterwakilan perempuan di struktur politik formal. Representasi politik perempuan cukup penting jika kita ingin menempatkan demokrasi yang ramah gender (gender democracy). Pada masa Orde
Lama dan Orde Baru, keterwakilan perempuan mengalami pasang surut, sedangkan pada masa reformasi, keterwakilan perempuan mengalami peningkatan. Guna peningkatan kualitas demokrasi yang berorientasi kesejahteraan rakyat, perlu keseimbangan peran perempuan dalam proses pengambilan keputusan politik di lembaga legislatif.

Studi ini akan menjawab berbagai masalah peran perempuan. Argumentasinya mentalitas yang terbangun di kalangan perempuan masih mentalitas warisan masa lampau. Keberadaan perempuan selalu dipersepsikan di bawah kuasa laki-laki. Sampai pasca reformasi, perempuan belum maksimal tampil ke publik. Mental patriakis warisan Orde Baru, masih menghantuinya. Agar perempuan tidak terbelenggu di bawah bayang-bayang kuasa patriarkis, hendaknya mental itu segera dihilangkan. Maka perempuan akan bisa berperan maksimal dalam parlemen!. 


\section{Budaya Patriaki}

Relasi antara laki-laki dan perempuan merupakan tema yang tidak tak kunjung usai. Bahkan, Erich Fromm mengatakan bahwa pertentangan yang terjadi antara relasi kedua jenis kelamin ini telah berlangsung sejak enam ribu tahun silam (Fromm, 2000:176). Persoalan menjadi semakin menguat ketika dalam relasi ini terjadi ketimpangan dan terdapat hubungan subordinasi. Bentuk penentangan perempuan atas kuasa laki-laki tidak terlepas dari sistem patriarki yang tidak adil yang menempatkan perempuan sebagai bayang-bayang laki-laki.

Kata patriarki mengacu pada sistem budaya dalam arti sistem kehidupan diatur oleh sistem "kebapakan". Patriarki atau "Patriarkat" merujuk pada susunan masyarakat menurut garis Bapak. Ini adalah istilah yang menunjukkan ciri-ciri tertentu pada keluarga atau kumpulan keluarga manusia, yang diatur, dipimpin, dan diperintah oleh kaum bapak atau laki-laki tertua. Artinya, hukum keturunan dalam patirarkat menurut garis bapak. Nama, harta milik, dan kekuasaan kepala keluarga (bapak) diwariskan kepada anak laki-laki (Ensiklopedia Indonesia 1984).

Kini istilah itu secara umum digunakan untuk menyebut "kekuasaan lakilaki". Khususnya hubungan kekuasaan antara laki-laki terhadap perempuan yang di dalamnya berlangsung dominasi laki-laki atas perempuan yang diwujudkan melalui bermacam-macam cara dan media (Bhasin, 1996). Sistem kebapakan ini menjadi cara pandang yang berlaku secara umum, sehingga otomatis kaum perempuan tidak terepresentasikan dalam cara pandang ini. Jika kita lihat, sistem budaya patriarki seakan-akan sudah menjadi alamiah dari asal muasalnya. Oleh karena itu, pandangan yang beranggapan bahwa kaum perempuan secara kodrati memang lebih lemah dari kaum laki-laki juga seakan-akan merupakan cara pandang yang "given".

Masyarakat patriarki sejak awal menganggap bahwa laki-laki lebih kuat dibandingkan perempuan baik dalam kehidupan pribadi, keluarga, masyarakat, maupun bernegara. Perbedaan biologis antara laki-laki dan perempuan dianggap sebagai awal pembentukan budaya patriarki. Perbedaan biologis antara keduanya merupakan status yang tidak setara. Perempuan yang tidak memiliki otot dijadikan alasan mengapa masyarakat menempatkan mereka pada posisi lemah. Hampir semua bidang politik didominasi kaum laki-laki. Mereka tidak berperan di dalamnya. Seolah-olah ada anggapan bahwa kehidupan politik bukan dunianya. Mengingat sifatnya yang mengandung kekerasan, ketidakjujuran, maupun tipu muslihat. Stereotip peran seksual yang ada, mengatakan bahwa politik adalah dunia lakilaki. Bila kita membicarakan peran politik perempuan, kita tidak bisa mengartikan politik secara sempit seperti melihat politik dalam kaca mata formal di bidang legislatif, eksekutif, dan yudikatif. Oleh karena eksistensi politik terwujud dalam aspek kehidupan bersama pada tingkat lokal maupun kepekaan terhadap permasalahan yang ada.

Murniati mendefinisikan patriarki sebagai suatu system laki yang berkuasa untuk menentukan segala sesuatu yang akan dilakukan atau tidak dilakukan (2004: 8). Sistem ini dianggap wajar sebab pembenarannya disejajarkan dengan pembagian kerja berdasarkan seks atau jenis kelamin dan bukan berdasarkan gender. Di samping itu, Murniti juga mengungkapkan, ada yang meyakini bahwa kekuasaan yang mengkontrol dan mendominasi pihak lain(2004:171). Pihak lain in menurut yang meyakini definisi tersebut adalah kelompok miskin, lemah, rendah, tidak berdaya, juga lingkungan hidup dan perempuan. Dalam budaya patriarki, negara yang menganut budaya tersebut disebut patriarkis.

Saraswati mengatakan bahwa
patriarkis adalah negara yang mempromosikan dan memelihara praktekpraktek yang secara langsung dan sistematis menindas perempuan (2004:31). Penindasan perempuan dilihat dari struktur keluarga dan rumah tangga serta kebijaksanaannya yang diterapkan pada kedua bidang tersebut. Biasanya, kebijakan tersebut bersifat diskriminatif, atau menghambat status kebebasan dan ekonomi bagi perempuan. 
Lebih lanjut mengungkapkan kelemahan-kelemahan perempuan akibat budaya patriarki adalah: (1) Perempuan kurang menyadari bahwa dirinya adalah seorang pribadi yang mempunyai hak-hak azasi manusia yang sama; (2) Perempuan seringkali kesulitan menghilangkan perasaan malu dan perasaan takut salah; (3) Perempuan kurang mampu berpikir jenih dan logis, sehingga sulit dalam mengambil keputusan; (4) Perempuan memiliki beban kerja domestik; (5) Perempuan selalu mempertimbangkan faktor (5) Perempuan selalu mempertimbangkan faktor keluarga, atau tradisi turun temurun keluarga yang aktif di organisasi; (6) Perempuan selalu mempertimbangkan faktor kesamaan agama; (7) Perempuan selalu mempertimbangkan faktor ekonomi; (8) Perempuan kurang dapat menerima kekuasaan (yang dipercayakan) dan dalam merebut kekuasaan lebih suka mengalah; (9) Perempuan kurang mampu mengendalikan emosi, sehingga pikirannya kurang stabil dan mudah terpengaruh; (10) Perempuan tidak mampu menjalin persatuan yang solid, sehingga mudah tercerai berai dan sukar menyatukan pandangan (Murniati, 2004:118).

Rezim Orde Baru telah membentuk kementerian khusus menangani masalah perempuan. Secara normatif, perempuan ikut berperan di bidang sosial maupun politik. Meski begitu, orientasi politik Orde Baru tetap menyuburkan pola politik patron-client dan kultur hegemoni "politik lelaki". Masuk di era reformasi, Menteri Negara Pemberdayaan Perempuan (terutama di era kepemimpinan Khofifah Indar Parawansa), mengangkat isu kesetaraan jender sebagai mainstream. Namun, kerja keras para menteri perempuan, para aktivis, dan berbagai organisasi perempuan di Tanah Air untuk mewujudkan persamaan hak tetap saja terbentur oleh budaya patriarki dan praktik politik anti partisipasi. Oleh karena dalam struktur masyarakat patriarkis, konstruksi sosial-budaya perempuan kerap dipakai sebagai alat legitimasi kekuasaan.

Budaya patriarki dan nilai-nilai sosial di Indonesia menuntut perempuan untuk tidak berpartisipasi di ranah politik maupun pemerintahan. Politik dianggapnya wilayah istimewa laki-laki (UNDP, 2010). Kendala yang biasa dihadapi perempuan berupa peran, tanggungjawab domestik, status subordinasi dalam hubungan gender serta perilaku sosial yang bersifat patriarkis. Perempuan kurang siap menjalankan peran publiknya. Umumnya mereka bukanlah pengambil keputusan, baik di bidang sosial, ekonomi dan politik. Apalagi sebagian besar masyarakat kita berpandangan bahwa . lakilaki harus menjadi pengambil keputusan dan pemimpin di kalangan masyarakat. Selain itu, laki-laki harus menjadi kepala rumah tangga. Sebaliknya, masyarakat menyatakan bahwa perempuan tidak boleh bekerja tanpa ijin dari suami mereka. Temuan dalam survey itu menunjukkan bahwa bias gender dalam pengetahuan dan perilaku masyarakat keseharian tetap eksis. Oleh karena adanya bias sosio-budaya, perempuan tertinggal dalam mengakses sumber daya produktif, misalnya tanah, kredit, aset materiil, pengembangan keterampilan, dll. Perempuan juga mengalami kekurangan dalam hal modal, karena mereka bukanlah pemimpin dan tidak memiliki basis kekuasaan yang mandiri.

Sistem dan arah kebijakan pemerintah terhadap isu perempuan kian responsif jender. Namun demikian, posisi perempuan tetap rentan terhadap berbagai bentuk manipulasi politik dan sering dipakai sebagai alat legitimasi. Asumsinya, perempuan sebagai unit utama kehidupan keluarga dan masyarakat. Kontrol atas peran perempuan merupakan sarana efektif dalam mengendalikan seluruh kekuasaan negara. Sementara bagi Fatimah Muhibbi (2005), feminis muslim Iran, perbedaan fisik perempuan dan laki-laki merupakan fakta yang tidak bisa ditolak (sunatullah). Namun, jika perbedaan itu dibingkai dalam konstruksi budaya yang bias jender (apalagi jika ia dibingkai dalam ayat-ayat agama) maka definisi persamaan hak atas dasar klaim perbedaan alamiah itu akan kembali berujung pada ekspresi dan dominasi politik patriarki. Secara substantif bertentangan dengan hukum Tuhan dan prinsip keadilan universal (Jurnal Sosial Demokrasi Edisi 6 Tahun 2 Juni - Agustus 2009 hlm. 6,7 dan 8). 
Berbagai regulasi negara menyangkut isu perempuan membuktikan bahwa konstruksi budaya politik patriarki sepanjang sejarah amat menentukan kehidupan perempuan. Sejak tahun 1960-an, gerakan feminisme menggeliat di berbagai belahan dunia. Termasuk di Indonesia para aktivis pada tahun 1990-an, terus menggugat dasar kebijakan negara yang bias jender. Mereka mendorong peran, fungsi, dan posisi perempuan secara lebih progresif, serta memprotes berbagai kebijakan konservatif. Diantaranya, negara dan stigma masyarakat yang memarjinalisasi aspirasi, hak, dan kepentingan perempuan.

Kaum feminis yang peduli pada pentingnya kesetaraan jender dalam membangun watak bangsa, menuntut perubahan yang progresif atas posisi perempuan. Hal ini tercermin dalam polemik isu poligami, isu kekerasan dalam rumah tangga, isu hak-hak reproduksi perempuan, atau isu peraturan daerah tentang pelacuran. Menurut Gadis Arivia (2006), hampir seluruh regulasi negara yang terkait dengan soal perempuan mengandung materi bias jender. Sebab, dalam struktur masyarakat patriarkis, konstruksi sosialbudaya perempuan kerap digunakan sebagai alat legitimasi politik.

Legitimasi ini terlihat dari sikap masyarakat yang sering menempatkan seksualitas perempuan sebagai komoditas; alat pemuas hasrat seksual laki-laki. Dalam kekuasaan berstruktur patriarkis, politik bukan hanya refleksi dari interest kekuasaan dan uang, tetapi juga seks. Terbongkarnya kasus mesum politisi DPR dengan artis dangdut beberapa waktu lalu membuktikan kebenaran hipotesis menyatunya "kekuasaan, uang, dan seks". Kuasa politik bukan cuma membuat para aktornya menjadi banal (politik haus kuasa), tapi juga binal (bukan cuma haus uang dan kuasa, tapi juga sarat syahwat).

Pesan penting dari terbongkarnya kasus mesum politisi DPR di atas, kemerosotan moral politik di level elite bukan hanya ditandai oleh banality of politics, tapi juga oleh binalitas manusia yang kian menunjukkan watak dasarnya sebagai homo sexus. Lebih dari itu, mesum DPR kian memperkuat argumen bahwa posisi perempuan di negeri ini masih berada di bawah kekokohan dominasi budaya politik patriarki. Kaum feminis yang menganut paham pluralisme demokratis meyakini bahwa perempuan tidak bisa dirugikan hanya karena jenis kelaminnya. Sebagai Manusia, perempuan juga butuh pengakuan atas eksistensi keperempuanannya. Gerakan feminis menentang pandangan stereotif yang berpotensi memarjinalisasi peran perempuan sebatas fungsi domestiknya, bukan dalam konteks kehidupan publik yang lebih luas.

\section{Partisipasi Politik dan Kebijakan}

Herbert McClosky berpendapat, partisipasi politik adalah kegiatan-kegiatan sukarela dari warga masyarakat melalui mana mereka mengambil bagian dalam proses pemilihan penguasa, dan secara langsung atau tidak langsung, dalam proses pembentukan kebijakan umum (Herbert McClosky dalam Miriam Budiardjo, 2008:367). Lebih jauh Miriam Budiardjo mengatakan bahwa partisipasi adalah kegiatan seseorang atau kelompok orang untuk ikut serta secara aktif dalam kehidupan politik, antara lain dengan jalan memilih pimpinan Negara dan secara langsung atau tidak langsung, mempengaruhi kebijakan kebijakan pemerintah (public policy). Kegiatan ini mencakup tindakan memberikan suara dalam pemilihan umum, menghadiri rapat umum, mengadakan hubungan (contacting) atau lobbying dengan pejabat pemerintah atau anggota parlemen, menjadi anggota partai atau salah satu gerakan sosial dengan directionnya.

Dalam hubungannya dengan bernegara Samuel P. Huntington dan Joan M. Nelson memberi tafsiran secara eksplisit, partisipasi politik merupakan kegiatan warga yang bertindak sebagai pribadipribadi yang bermaksud mempengaruhi pembuatan keputusan pemerintah. Partisipasi bisa bersifat individual atau kolektif, terorganisir atau spontan, mantap atau sporadis, secara damai atau dengan 
kekerasan, legal atau illegal, efektif atau tidak efektif.

Di negara demokrasi konsep partisipasi politik berawal dari pemahaman bahwa kedaulatan ada di tangan rakyat. Untuk menentukan orang-orang yang memegang tampuk pimpinan, menetapkan tujuan-tujuan serta masa depan masyarakat diwujudkan melalui kegiatan bersama. Dengan demikian partisipasi politik merupakan pengejawantahan dari penyelenggaraan kekuasaan politik yang absah oleh rakyat.

Pasal 27 ayat (1) Undang-Undang Dasar Negara Republik Indonesia Tahun 1945 menegaskan, bahwa kedudukan lakilaki dan perempuan sebagai warga negara adalah setara. Demikian pula Deklarasi Universal Hak Asasi Manusia Tahun 1948 sesungguhnya telah menegaskan persamaan hak laki-laki dan perempuan. Namun masyarakat internasional menyadari, untuk mewujudkan hak-hak perempuan dalam kehidupan sehari-hari memerlukan kebijakan khusus. Kesadaran ini didasarkan pada kenyataan bahwa perempuan di seluruh dunia masih mengalami nasib buruk: pertama, perempuan dianggap lebih rendah kedudukannya daripada laki-laki; kedua, perempuan lebih sulit mengakses pendidikan, kesehatan dan kesempatan kerja daripada laki-laki.

Realitas sosial tersebut membuat Perserikatan Bangsa Bangsa (PBB) sangat peduli pada isu perempuan. Pada 7 Juli 1954 Majelis Umum PBB mengadopsi Konvensi Hak-Hak Politik Perempuan atau Convention on the Political Right of Women (CPRW). Lalu, pada 18 Desember 1979, Majelis Umum PBB mengadopsi Konvensi Penghapusan Segala Bentuk Diskriminasi terhadap Perempuan atau Convention on the Elimination of All Forms of Discrimination Against Women (CEDAW).

Implementasi dari dua dokumen itu selama beberapa dasawarsa belum mengalami kemajuan yang signifikan, sehingga Konferensi Dunia IV tentang Perempuan 1995 di Beijing China, mengeluarkan Deklarasi Beijing Platform for Action (BPFA). Deklarasi ini menegaskan, demi meningkatkan kesadaran akan hak perempuan, perlu dilakukan pendidikan tentang hak-hak perempuan dan dibentuk badan-badan yang bertugas melindungi perempuan dari pelanggaran hak-haknya. Selanjutnya memasuki Abad ke-21, Sidang Umum PBB yang dihadiri oleh 189 negara di dunia membuat deklarasi Delapan Tujuan Pembangunan Milinium (Millennium Development Goals/MDGs), yang dalam tujuan ke-3 adalah Pemberdayaan Perempuan dan Promosi Kesetaraan Gender dalam berbagai aspek pembangunan.

Pemerintah Indonesia meratifikasi CPRW melalui Undang-Undang Nomor 68 Tahun 1958 tentang Persetujuan Konvensi Hak-Hak Politik Kaum Wanita, dan CEDAW melalui Undang-Undang Nomor 7 Tahun 1984 tentang Pengesahan Konvensi Mengenai Penghapusan Segala Bentuk Diskriminasi terhadap Perempuan. Sebelum meratifikasi CEDAW, sejak 1978 pemerintah telah membentuk Kementerian Negara Urusan Wanita, yang secara khusus mengkoordinasi usaha-usaha untuk meningkatkan kesejahteraan perempuan melalui program pendidikan, ekonomi dan kesehatan

Kebijakan khusus bagi perempuan di bidang politik baru diterapkan pasca pemilu 1999. Pada tahap awal, kebijakan tersebut tercantum dalam Undang-Undang Nomor 31 Tahun 2002 tentang Partai Politik. UndangUndang ini menyatakan, bahwa kepengurusan partai politik harus memperhatikan kesetaraan dan keadilan gender. Meski rumusan "memperhatikan kesetaraan dan keadilan gender" itu sangat abstrak dan tidak terukur, namun undangundang itu merupakan pijakan pertama untuk mengembangkan kebijakan lebih lanjut.

Dalam mengadopsi kebijakan khusus, undang-undang berikutnya menggunakan rumusan kuota minimal 30\% keterwakilan perempuan. Angka 30\% itu merupakan kesimpulan dari studi United Nations Divisions for the Advancement of Women (UN-DAW), bahwa suara dan kepentingan perempuan baru diperhatikan dalam kehidupan publik, apabila mencapai 30\%. Atas dasar ini Undang-Undang Nomor 12 Tahun 2003 tentang Pemilu Anggota DPR, 
DPD dan DPRD menggunakan rumusan kuota minimal $30 \%$ keterwakilan perempuan dalam daftar calon anggota legsilatif untuk Pemilu 2004.

Lima tahun kemudian, kebijakan tindakan khusus sementara dalam bentuk kuota minimal $30 \%$ keterwakilan perempuan diterapkan dalam UndangUndang Nomor 2 Tahun 2008 tentang Partai Politik. Undang-Undang ini menyatakan, bahwa pendirian dan kepengurusan partai politik memperhatikan sedikitnya 30\% keterwakilan perempuan. Selanjutnya, kuota minimal $30 \%$ keterwakilan perempuan dalam daftar calon anggota legislatif juga diperbaiki komposisinya, sebagaimana diatur dalam Undang-Undang Nomor 10 Tahun 2008 tentang Pemilu Anggota DPR, DPD dan DPRD.

Ketentuan tersebut dipertahankan dalam Undang-Undang Nomor 8 Tahun 2012 tentang Pemilu Anggota DPR, DPD dan DPRD. Tentu saja implementasi undangundang partai politik dan undang-undang pemilu legislatif tersebut masuk dalam kerangka Undang-Undang Nomor 17 Tahun 2007 tentang Rencana Pembangunan Jangka Panjang Nasional Tahun 2005-2025. Namun para perumus konstitusi menyadari, kesetaraan itu tidak serta merta terwujud dalam kehidupan sehari-hari. Sejarah mencatat, tidak terlalu besar perempuan yang terlibat dalam pengambilan keputusan di lembaga legislatif. Hal tersebut terlihat pada tabel di bawah ini:

\begin{tabular}{|c|c|c|}
\hline Masa Kerja & Perempuan & $\begin{array}{c}\text { Laki- } \\
\text { laki }\end{array}$ \\
\hline $\begin{array}{c}1950-1955 \\
\text { (DPRS) }\end{array}$ & $9(3.8 \%)$ & $\begin{array}{c}236 \\
(96.2 \%)\end{array}$ \\
\hline $1955-1960$ & $17(6.3 \%)$ & $\begin{array}{c}272 \\
(93.7 \%)\end{array}$ \\
\hline $\begin{array}{c}1956-1959 \\
\text { (Konstituante) }\end{array}$ & $25(5.1 \%)$ & $\begin{array}{c}488 \\
(94.9 \%)\end{array}$ \\
\hline $1971-1977$ & $36(7.8 \%)$ & $\begin{array}{c}460 \\
(92.2 \%)\end{array}$ \\
\hline $1977-1982$ & $29(6.3 \%)$ & $\begin{array}{c}460 \\
(93.7 \%)\end{array}$ \\
\hline $1982-1987$ & $39(8.5 \%)$ & $\begin{array}{c}460 \\
(91.5 \%)\end{array}$ \\
\hline $1987-1992$ & $65(13 \%)$ & 500 \\
\hline
\end{tabular}

\begin{tabular}{|c|c|c|}
\hline & & $(87 \%)$ \\
\hline $1992-1997$ & $62(12.5 \%)$ & $\begin{array}{c}500 \\
(87.5 \%)\end{array}$ \\
\hline $1997-1999$ & $54(10.8 \%)$ & $\begin{array}{c}500 \\
(89.2 \%)\end{array}$ \\
\hline $1999-2004$ & $46(9 \%)$ & $\begin{array}{c}500 \\
(91 \%)\end{array}$ \\
\hline $2004-2009$ & $61(11.8 \%)$ & $\begin{array}{c}489 \\
(88.9 \%)\end{array}$ \\
\hline $2009-2014$ & $\begin{array}{c}101 \\
(18,10 \%)\end{array}$ & $\begin{array}{c}459 \\
(82 \%)\end{array}$ \\
\hline $2014-2019$ & $\begin{array}{c}97(17,3 \\
\%)\end{array}$ & $\begin{array}{c}463 \\
(86,3 \\
\%)\end{array}$ \\
\hline
\end{tabular}

Sumber: Sekretariat Jenderal DPR RI, 2014

\section{Basis Keterpilihan}

Secara umum jumlah keterpilihan perempuan sebagai anggota legislatif hasil Pemilu 2014 mengalami penurunan dibandingkan Pemilu 2009. Puskapol FISIP UI mencatat perolehan kursi anggota legislatif 2014-2019 sbb:

Hasil Pemilu 2009, perempuan meraih 101 (18\%) kursi Dewan Perwakilan Rakyat (DPR) dan 36 (27\%kursi Dewan Perwakilan Daerah (DPD). Untuk DPRD Provinsi, perempuan meraih kursi DPRD rata-rata 16\% dari 33 provinsi, dan kursi DPRD Kabupaten/Kota rata-rata $12 \%$ dari 487 kabupaten/kota se Indonesia. Gambaran jelas dari komposisi perolehan kursi legislatif untuk perempuan di tingkat provinsi dan kabupaten/kota dapat dapat dipetakan:

Pertama, keterwakilan perempuan di 33 DPRD Provinsi, hanyalah Provinsi Maluku yang mencapai target 30\% kursi DPRD-nya. Sedangkalan di 32 provinsi lainnya dapat dikategorikan: kluster satu di 5 provinsi meraih kursi antara 21\% - 25\%, kluster dua di 16 provinsi meraih kursi $11 \%$ - 20\%, dan kluster tiga di 11 provinsi meraih kursi $2 \%$ $10 \%$.

Kedua, keterwakilan perempuan DPRD di 488 Kabupaten/Kota dapat diidentifikasi: hanyalah 7 kota yang dapat meraih kursi diatas 30\%; sedangkan di 481 
kabupaten/kota lainnya dapat diklusterkan sebagai berikut: kluster satu terdapat di 35 kabupaten/kota perempuan meraih kursi DPRD 21\% - 29\%; kluster dua di 192 kabupaten/kota perempuan meraih kursi DPRD 11\% - 20\%, kluster tiga di 210 kabupaten/kota perempuan meraih kursi DPRD 2\% - 10\%, dan kluster empat di 44 kabupaten/kota $(9,03 \%)$ perempuan tidak meraih kursi DPRD-nya. Selain itu terdapat di 68 dari 488 Kabupaten/Kota hanya satu keterwakilan perempuan DPRD-nya yang rentan kosong karena setiap terjadi pergantian antarwaktu yang mengganti bukan perempuan.

Hasil Pemilu Legislatif 2014 menunjukkan tidak adanya partai yang mendominasi perolehan kursi di DPR RI. Perolehan kursi paling tinggi dicapai oleh PDI-P (19.46\%), disusul Golkar (16,25\%), dan Gerindra (13,03\%). Jumlah kursi masing-masing partai menengah juga menunjukkan selisih tipis (kurang dari $2 \%$ antar partai). Hal ini menunjukkan kekuatan partai-partai politik di parlemen semakin berimbang.

Perolehan kursi perempuan di parlemen yang terbesar berasal dari PDIP (21,65\%), disusul oleh Golkar (16,49\%), dan Partai Demokrat $(13,40 \%)$. Jumlah kursi terkecil perempuan di parlemen berasal dari PKS, yakni 1 perempuan dari 40 orang $(1,03 \%)$. Dibandingkan dengan tahun 2009, penurunan jumlah perolehan kursi perempuan di DPR RI paling signifikan terjadi pada Partai Demokrat (turun 22). Sementara itu, ke naikan jumlah perolehan kursi perempuan di DPR RI paling banyak terjadi di Partai Gerindra (naik 7), diikuti oleh PDIP dan PPP (masing-masing naik 5). Calon DPR RI dengan nomor urut 1 masih mendominasi keterpilihan sebagai anggota legislatif. Data hasil Pemilu 2014 dan 2009 menunjukkan sebagian besar caleg yang terpilih (di kisaran 60\%) berada pada nomor urut 1. Sebagian besar caleg terpilih adalah anggota baru (57\%) dengan sebaran yang cenderung sama pada anggota laki-laki (56\% baru) dan anggota perempuan (60\% baru).

Survei Puskapol UI menemukan empat macam basis keterpilihan anggota DPR dan DPD yaitu: keterpilihan ekonomi, dan jaringan kekerabatan dengan elite politik. Di DPR RI, sebanyak 242 orang (43.2\%) adalah petahana. Mayoritas dari petahana adalah anggota laki-laki (84\% atau 203 orang) sementara anggota perempuan hanya $16,1 \%$ (39 orang). Partai dengan persentase anggota petahana terbesar berturut-turut adalah PKS (68\%), Demokrat dan PPP (masing-masing 54\%), PAN (53\%). Sedangkan partai dengan persentase anggota baru terbanyak adalah Partai Nasdem (97\%, baru sekali mengikuti pemilu) dan Partai Gerindra (84\%). Untuk anggota DPD, sebanyak 40,2\% (53 dari total 132 orang) adalah petahana, sementara 59,8\% (79 dari 132 orang) adalah anggota baru. Dari 53 petahana, anggota laki-laki sebanyak $66 \%$ (35 orang) dan pe rempuan $34 \%$ (18 orang). Artinya, jumlah anggota petahana laki-laki hampir dua kali lipat lebih banyak dibandingkan perempuan.

Sebanyak 15\% anggota DPR 20142019 berasal dari anggota DPD/DPRD. Signifikannya jumlah anggota yang berasal dari DPRD menunjukkan sinyal positif dalam proses rekrutmen partai yang melihat pada rekam jejak dan basis konstituen di daerah. Sehingga, bisa memunculkan kesinambungan proses kaderisasi partai di daerah dan nasional. Dari anggota DPR RI yang basis keterpilihannya dari anggota DPD/DPRD, mayoritas adalah anggota laki-laki $(83,5 \%)$. Sedangkan untuk anggota DPD terpilih yang mantan anggota DPR/DPRD sebanyak 62 orang atau $47 \%$, yang mayoritas adalah lakilaki (82\% atau 51 orang). Sebanyak 29\% anggota DPR RI memiliki latar belakang sebagai elite ekonomi (pengusaha). Dari jumlah itu, hampir seluruhnya adalah anggota laki-laki (91,4\%). Hal ini mengindikasikan kekuatan finansial mayoritas dimiliki oleh anggota laki-laki. Sementara di DPD, terdapat $10,6 \%$ atau 14 orang anggota yang memiliki latar belakang elite ekonomi. Dari jumlah itu, sebagian kecil adalah per- empuan (36 \%) dan lainnya lakilaki (64\%).

Jaringan kekerabatan dengan elite politik sebagai salah satu basis keterpilihan anggota legislatif merupakan fenomena yang harus disikapi secara serius. Meskipun jumlahnya belum terlihat besar 
dibandingkan basis keterpilihan yang lainnya, hal ini mencerminkan sempitnya basis rekrutmen politik baik yang dilakukan partai politik (DPR) maupun jalur perseorangan (DPD).

Di DPR terdapat 13,8\% (77 orang dari 560) teridentifikasi memiliki jaringan kekerabatan dengan elite politik. Dari jumlah tersebut, ada 53\% laki-laki (41 orang) dan $47 \%$ perempuan (36 orang).Sedangkan di DPD terdapat 15\% (20 orang dari 132) yang teridentifikasi memiliki jaringan kekerabatan dengan elite politik. Mayoritas adalah anggota perempuan (13 orang atau 65\%) dan anggota laki-laki hanya 7 orang $(35 \%)$.

Fenomena jaringan kekerabatan di balik keterpilihan anggota legislatif mencerminkan pencalonan yang rawan politik transaksional yang melibatkan segelintir orang dalam partai (potensi terjadinya "politik dinasti"). Selain itu, fenomena kekerabatan juga cenderung menghilangkan otonomi individu anggota legislatif dalam kerja-kerja perwakilan akibat pengaruh pertalian keluarga dengan elite politik yang berkuasa. Mencermati profil dan basis keterpilihan anggota legislatif DPR RI 2014-2019, sangat berpeluang kuatnya dominasi fraksi atas otonomi anggota. Hal ini terutama disebabkan oleh pola basis rekrutmen yang mengandalkan kekuatan finansial dan kekerabatan untuk mendukung elektabilitas yang tinggi. Antara lain ditunjukkan oleh 7 dari 77 anggota terpilih yang memiliki jaringan kekerabatan termasuk dalam 10 besar peraih suara tertinggi.

Kecenderungan semakin kuatnya dominasi fraksi atas anggota legislatif ditunjukkan pula oleh berimbangnya jumlah petahana terpilih dan anggota baru terpilih. Sebagian petahana yang tidak terpilih dapat diidentifikasi sebagai anggota yang kritis terhadap posisi dan kebijakan partai/fraksi. Dengan kondisi ini, harapan agenda reformasi parlemen dan lahirnya kebijakan yang pro kepentingan publik akan berhadapan dengan kepentingan oligarki (elite politik/ fraksi). Untuk anggota DPD, sebanyak $40,2 \%$ (53 dari total 132 orang) adalah petahana sementara 59,8\% (79 dari
132 orang) adalah anggota baru. Dari 53 petahana, anggota laki-laki sebanyak 66\% (35 orang) dan perempuan 34\% (18 orang). Artinya, jumlah anggota petahana laki-laki hampir dua kali lipat lebih banyak dibandingkan perempuan.

Sebanyak 15\% anggota DPR 20142019 berasal dari anggota DPD/DPRD. Signifikannya jumlah anggota yang berasal dari DPRD menunjukkan sinyal positif dalam proses rekrutmen partai yang melihat pada rekam jejak dan basis konstituen di daerah. Hal ini bisa memunculkan kesinambungan proses kaderisasi partai di daerah dan nasional. Dari anggota DPR RI yang basis keterpilihannya dari anggota DPD/DPRD, mayoritas adalah anggota laki-laki $(83,5 \%)$. Sedangkan untuk anggota DPD terpilih yang mantan anggota DPR/DPRD sebanyak 62 orang atau $47 \%$, yang mayoritas adalah lakilaki ( $82 \%$ atau 51 orang).

\section{Pendidikan Politik}

Ketika melakukan partisipasi di publik, perempuan menghadapi banyak tantangan dan keterbatasan. Umumnya, mereka sulit masuk ke ranah politik. Selain menyangkut finansial, basis sosialnya dianggapnya juga lemah. Kondisi inilah yang kemudian menimbulkan prasangka sosial adanya ketimpangan gender di ranah publik.

Keterwakilan perempuan di lembaga legislatif sangat minim. Oleh karenanya aspirasi kaum perempuan dalam perumusan kebijakan publik yang sensitif gender kurang mendapat perhatian. Banyak perempuan kurang tertarik pada aktivitas politik sehingga mereka enggan menjadi anggota partai politik. Politik dianggapnya kotor dan miliknya laki-laki. Padahal politik bukan sekadar kompetisi meraih kekuasan, melainkan juga ruang merumuskan kebijakan pemerintahan. Mewujudkan kesejahteraan rakyat yang berkeadilan secara inklusif. Untuk itu diperlukan strategi agar perempuan tertarik masuk ke dunia politik, menjadi anggota partai politik, menjadi kader yang aktif dalam kegiatan partai politik, dan menjadi pengurus partai politik. 
Perubahan dalam hal persepsi dan perilaku publik terhadap peran perempuan merupakan cara membuka kesempatan sosial politik. Meskipun demikian perubahan sosial tidak terjadi dengan mudah dan perlu terus diperjuang-kan.

Dalam kehidupan sehari-hari,
perempuan lebih tahu terhadap
kebutuhannya. Misalnya masalah kesehatan
reproduksi, kesehatan keluarga, harga
sembilan bahan pokok, pendidikan anak,
kekerasan dalam rumah tangga, kekerasan
seksual, diskriminasi di tempat kerja,
maupun diskriminasi di hadapan hukum.
Menjadi sangat penting bagi perempuan,
ikut menjadi pembuat keputusan politik.
Keikutsertaan perempuan dalam pembuatan
keputusan publik, tentunya dapat mencegah
segala bentuk diskriminasi atau kebijakan
yang kurang berpihak kepada mereka.

Lembaga swadaya masyarakat dapat mensosialisasikan pentingnya peningkatan partisipasi politik perempuan kepada masyarakat. Demikian pula pendidikan politik dan pendidikan pemilih untuk perempuan dalam rangka peningkatan kesadaran politik perempuan serta mengubah visi politik mereka. Dalam pendidikan politik, pengertian politik hendaknya diredefinisi sesuai perspektif perempuan. Termasuk peningkatkan keterampilan kepemimpinan mereka. Pendidikan pemilih tidak hanya diarahkan bagaimana melakukan pencoblosan dan pemantauan pemilu, melainkan juga pentingnya pemenuhan kuota 30\%.. Demikian pula peningkatan keterampilan mereka melakukan advokasi.

Selain itu memberikan dukungan penuh bagi kandidat perempuan agar tampil secara meyakinkan. Ketika mereka telah menjadi legislator dukungan tersebut terus berlanjut dengan menyediakan berbagai informasi yang diperlukan bagi tugas-tugas nya Memastikan para anggota parlemen dapat berpartisipasi dalam melakukan reformasi kebijakan dan peraturan perundangan yang diskriminatif, tidak berperspektif gender. Membentuk kaukus perempuan sebagai sarana lobi guna memastikan bahwa perspektif perempuan dipertimbangkan dalam setiap keputusan yang akan diambil.

Dalam perspektif perempuan, politik hendaknya mencakup semua kehidupan baik di ranah publik maupun privat. Oleh karena itu, kita perlu terus menerus mendesakkan agenda politik kaum perempuan agar menjadi agenda politik partai. Kaukus parlemen perempuan dan kaukus perempuan politik yang telah ada perlu didukung. Selain itu perlu diperkuat dalam mempengaruhi peraturan perundangan, penganggaran, dan peran-peran pemantauan tata kelola pemerintahan lainnya.

Saat ini belum ada keterkaitan formal antara para perwakilan perempuan yang bekerja di berbagai tingkatan pemerintahan. Dibentuknya jejaring yang secara vertikal mengaitkan dengan para perwakilan perempuan di tataran lokal, regional dan nasional akan membantu dalam memperkuat kapasitas dan kebersamaan para perwakilan perempuan. Para perwakilan perempuan juga dapat menciptakan basis kekuatan mereka sendiri dan saling membantu sama lain dalam mendorong agenda kesetaraan gender dalam agenda program kerja parlemen.

Keterkaitan antara perwakilan terpilih dan para pemilih masih lemah dalam demokrasi Indonesia. Kampanye peningkatan kesadaran publik secara nasional perlu diluncurkan. Modelnya bisa seperti iklan layanan masyarakat. Kampanye tersebut bisa dilakukan melalui media massa baik cetak maupun elektronik, serta media sosial. Tujuannya tiada lain merubah pola pikir masyarakat yang keliru tentang peran perempuan di ranah politik dan pemerintahan. Kampanye kesadaran publik harus menjadikan perempuan dan laki-laki sebagai sasaran.

Perempuan seringkali menginternalisasi ideologi peran gender dan juga meyakini stereotip gender yang dilekatkan pada mereka. Kampanye dengan setting iklan layanan masyarakat pendidikan pemilih bisa diintegrasikan dengan pendidikan politik dan kesadaran gender. Kampanye dilakukan terus-menerus dan berkesinambungan 


\begin{abstract}
Kurangnya keseimbangan gender di sektor politik dan pemerintahan menghambat partisipasi perempuan dalam ranah publik. Berkenaan dengan itu perlu ditumbuhkan gerakan kesadaran publik terhadap isue gender, praktik demokrasi, keadilan gender, peran dan tanggungjawab pemilih, serta perilaku yang mendukung partisipasi dan keterwakilan perempuan secara politis. Akses perempuan dalam politik merupakan prasyarat bagi partisipasi mereka. Namun tidak dengan sendirinya menghasilkan sebuah transformasi sosial maupun keadilan gender. Oleh karenanya kaum perempuan sendirilah yang harus memperjuangkananya.
\end{abstract}

\section{Penutup}

Partisipasi perempuan dalam bidang politik pada masa kini cenderung lebih positif. Sejak masa reformasi berbagai kebijakan berkait dengan pemberdayaan perempuan telah dikeluarkan oleh pemerintah. Kebijakan telah berpihak pada perempuan, sehingga kaum perempuan akan nyaman dalam berpolitik. Pendidikan politik diharapkan dapat mengubah image masyarakat tentang politik yang selama ini diasumsikan sebagai hak monopoli kaum lelaki. Demikian pula perlunya pencerahan pada masyarakat utamanya kaum perempuan bahwa hak politik merupakan bagian integral dari HAM. Peningkatan jumlah anggota dewan perempuan dari periode ke periode belum mampu mengentaskan kaumnya dari ketidaksetaraan gender yang dialami. Oleh karena itu, perjuangan perempuan untuk mewujudkan kesetaraan gender tidak dapat dilakukan oleh kaum perempuan sendiri, melainkan diperlukan kerjasama dengan entitas sosial lain yang memiliki kepekaan terhadap persoalan perempuan (gender sensitivity).

\section{Daftar Pustaka}

Gadis Arivia. 2006. Femininisme: Sebuah Kata Hati. Jakarta: Penerbit Buku Kompas.

Jurnal sosial Demokrasi Edisi 6 Tahun ke 2 Jakarta: Pergerakan Indonesia dan Komite Persiapan Yayasan Indonesia Kita, 2009.

Miriam Budiardjo, Dasar-Dasar Ilmu politik. Jakarta: PT. Gramedia Pustaka Utama, 2008.

Murniati. Getar Gender; Perempuan dalam Perspektif Agama Budaya dan Keluarga. Magelang: Tera, 2004

Nina Andriana dkk. Perempuan Partai Politik dan Parlemen: Studi Kinerja Anggota Legislatif Perempuan di Tingkat Lokal. Jakarta: LIPI, 2012

Peraturan Pemerintah No. 07 Tahun 2013 tentang "Panduan Peningkatan Partisipasi Politik Perempuan di Lembaga Legislatif.

Sylvia Walby. Teorisasi Patriaki. Yogyakarta: Jalasutra, 2014

Undang-Undang Nomor 17 Tahun 2007 tentang Rencana Pembangunan Jangka Panjang Nasional Tahun 2005-2025

Undang-Undang Nomor 10 Tahun 2008 tentang Pemilu Anggota DPR, DPD dan DPRD.

Undang-Undang Nomor 31 Tahun 2002 tentang Partai Politik 